\title{
THE TERRESTRIALIZATION \\ OF AMPHIBIOUS LIFE IN A DANUBE DELTA 'TOWN ON WATER'
}

\begin{abstract}
I}$
The Danube Delta town of Vilkovo is often called the 'Ukrainian Venice' because of its 40 kilometers of canals. Many of these canals, however, are rapidly filling in with silt and are often impassible by boat. Tourism entrepreneurs and town administrators have begun lobbying for funding for a large-scale canal restoration project and for the town's designation as a heritage site. Their tourism-development narratives, however, often overlook or simplify a complex set of social and environmental factors that have shaped residents' past and present relationships with the Danube River. This article counters this tendency by providing an ethnographic portrait of terrestrialization-a term I use to name the confluence of geomorphological, ecological and social change in Vilkovo-that draws on townspeople's descriptions of their dwelling practices. It combines insights from amphibious anthropology and social science literature on water infrastructure in order to pinpoint issues that need to be addressed in developing the town's tourist economy, and makes the case for including studies of terrestrialization as part of an amphibious anthropology.
\end{abstract}

Keywords: terrestrialization, amphibious anthropology, water infrastructure, sediments, Danube, Ukraine, Vilkovo/Vylkove

$\mathrm{I}^{\mathrm{n}}$ n the far southwest, where the Danube flows over the territory of our country before it drains into the Black Sea, on the left side of the riverbank there is only one settlement, Vilkovo... This town is unique: it stands on water literally, not figuratively. Canals and streams serve as streets...

There are many towns and settlements located on the banks of rivers, lakes, and seas, and the author of these lines has seen many of them on the Dnepr, Volga, Yenisei, Seine, and The
Thames. But nowhere have I seen such a complete and organic merging of a settlement with a river, where no clear boundary exists between them. - Aleksandr Rykovtsev Vilkovo (1984)

'My heart bleeds to look at this.' A shorthaired, trim, sportily dressed woman addressed these words to another woman, and to me, an ethnographer-stranger, as I stopped in front of their green gate and fence. Just prior to this encounter on a warm, clear mid-September 
evening in 2012, I had been watching an excavator dig up slurry at the confluence of the ten-meter-wide Shevchenko Canal and the Danube's Belgorod Channel in Vilkovo. I was mesmerized by the splash of the excavator's metal scoop as it broke the water's surface, and the splat the grey mud made as it slid from the scoop onto a bank reinforced with rusting metal. The day before, Vilkovo's deputy mayor had informed me about the town's plans to dig up part of Shevchenko Canal and to fill in part of the adjoining Chekhov Canal, so I decided to take a look. After crossing the wooden bridge to Chekhov Canal, I paused, disoriented as my memory of a reed-lined ditch concealing halfsubmerged tarred wooden fishing boats was displaced by a road covered with fresh red earth.

'This used to be a deep yerik', Nadia, the sportily clad woman explained. Then in tagteam fashion she and her sister Olga recalled the street of their youth: 'We used to fish and swim here.' 'We'd tan on the kladki.' 'When workers from the Ship Repair Enterprise came home for lunch, they'd have to step over us!' Yerik (derived from the Turkish word arik) is the term that Vilkovo's predominantly Russian-speaking residents use to refer to the town's canals, while $k l a d k i$ are the raised wooden sidewalks adjacent to them that enable residents to walk above water and mud. The sisters continued: 'But it is the right thing to do,' Nadia said. Olga carried on: 'This yerik used to flow. A yerik needs to flow... it needs to connect to the Danube. This one was a dead end; it was no longer connected to the Danube. The smell was terrible. So it's a good thing they filled it in. But it's very sad too.'

Our conversation moved from their memories of the yerik to an invitation to accompany Nadia on her walk home, most of which was along the concrete blocks of Vilkovo's main street (then called Lenin and now Birth of Christ). ${ }^{2}$ The two women-Russian Old
Believers ${ }^{3}$ - had married Ukrainian men and now resided in the Ukrainian part of town. During our walk, Nadia, who works as a teacher and as a tourist guide, talked about the challenges of living in Vilkovo's muddy landscape. She told a morbid legend about the construction of the Nativity of the Blessed Virgin Mary Old Believer Church in which workers had difficulties laying a foundation on soft ground. After deciding to pray, one worker dreamed that a saint said told him that if one of the men's wives were sacrificed-the first to approach the church-the builders would find a solution. A wife was sacrificed and the church was built. The not-so-solid earth surfaced again as we walked by multi-storied brick houses with steel roofs built by households where men worked as sailors on foreign commercial liners. Families with more modest incomes like hers lived in older, wood-frame houses built with reeds and silt. While Nadia preferred these buildings, they shift and crack easily 'because the land here is capricious' and thus require more frequent, labor-intensive maintenance.

Travellers' images of Vilkovo, like the one cited in the epigraph, emphasize the town's canals, boats, and wooden sidewalks that distinguish it not only from terrestrial towns but other river towns too (Figure 1). Images of a 'Ukrainian Venice'bordering globally significant Ramsar wetlands have circulated more widely since the late 1990s as first entrepreneurs and then town administrators have sought to develop a tourist economy-a strategy pursued throughout the former socialist world and in the Danube Delta (Banaszkiewicz et al. 2017; Ivan 2017)—to compensate for rural deindustrialization (Vaccaro et al. 2015). However, visitors often question the Venice comparison because of the town's rural character and because the canals are often impassible by boat (Dykhno 2015; Prylypko 


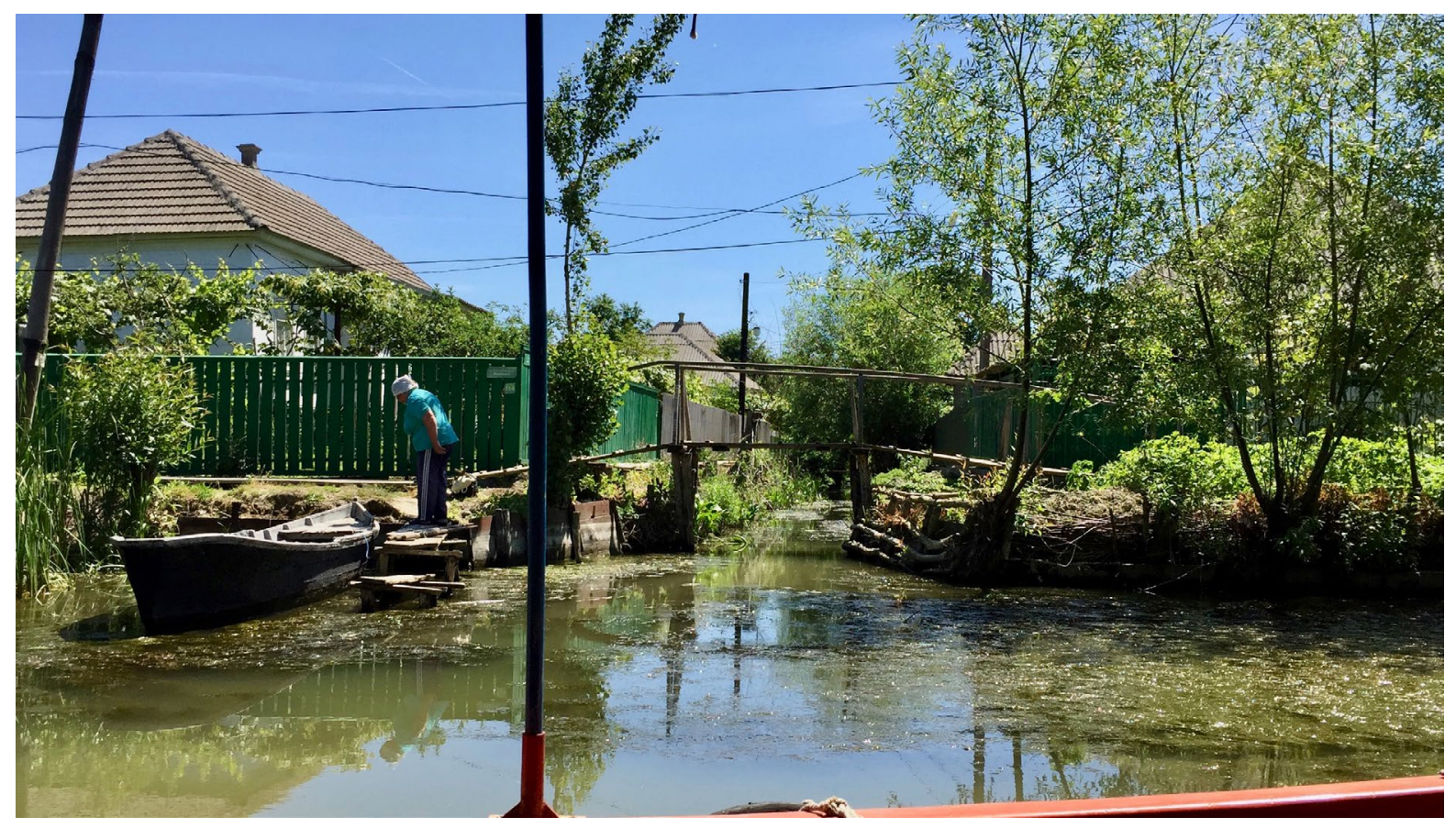

Figure 1: Photo of sidewalks and canals taken during an excursion on Belgorod Channel. Photo by Author.

2014). Consequently, development project entrepreneurs (mainly based in the region's capital of Odesa), in collaboration with town administrators, are applying to have Vilkovo designated as a national and UNESCO heritage site, as a unique example of $18^{\text {th }}$ and $19^{\text {th }}$-century city-planning in a delta environment, while the mayor's office is trying to mobilize funds for a large canal restoration project (Poltorak 2016). However, tourism-development narratives often assume that all residents-called Vilkovchanican and want to practice 'extraterrestrial life' (ukr. pozazemna zhyttia), a phrasing coined by a Kyiv-based travel writer that alludes to the alienness of this way of life in the contemporary terracentric Ukrainian national imaginary (cf. Prylypko 2014).

This paper provides an anthropological answer to the question, 'Why are Vilkovo's canals filling in with silt?' in order to make visible some of the long-term, multi-scalar, socionatural processes that shape the possibilities for an amphibious way of life, the social tensions to which they give rise, and the economic and ecological problems generated by an excess of silt. ${ }^{4}$ To do so, I juxtapose an ethnographic description of Vilkovchani's accounts of the dwelling practices that enabled them to maintain a way of life in the delta's fluctuating milieus with a description of how these practices have changed during and after socialism, and with recent attempts to clear canals. The research was conducted during seven weeks of ethnographic fieldwork in August and September 2012 as part of a project about the impact of changing environmental regulation and the creation of a biosphere reserve on landscapes and livelihoods in the Ukrainian part of the Danube Delta. It draws on open-ended conversations with 20 residents (mostly Old Believers) between the ages of 50 and 80 , and interviews with the town's deputy mayor, the owner of a firm that dredged the canals, an engineer involved in a project to clear the canals in the 
early 1990s, and administrators of the Danube Biosphere Reserve. My involvement in weeding, fruit-picking, digging canals, mixing silt plaster, expeditions, and tours with gardeners, small tour operators, fishermen, scientists and DBR staff during annual trips between 2008 and 2016 also informs this article. ${ }^{5}$

To answer this article's key question, I draw together and contribute to discussions in environmental anthropology about amphibiousness, delta life, and water infrastructure (e.g. Gagné and Rasmussen 2016; Krause 2017; Jensen 2017; Morita 2016; Carse 2014; Barnes 2014; Feaux de la Croix 2016; Chelcea and Pulay 2015; Pauwelussen and Verschoor 2017; Richardson 2018; Scaramelli 2018b). 'The amphibious'-a concept arising out of analyses of the distinct socialities, infrastructures and predicaments found in muddy places along rivers and coasts-works to subvert nature/ culture and land/water binaries that haunt not only the language of describing the earth's geomorphology (cf. Lahiri-Dutt 2014), but also environmental regulation where land and water codes are often separate legal acts. By emphasizing people's encounter with mud, and the fluctuation of milieus between solid, liquid, wet, and dry, 'the amphibious' can thus open up a way for apprehending the specific predicaments of Vilkovo's human and morethan-human landscapes. Political ecology and STS-informed studies of water infrastructure direct attention to geomorphological processes operating on more expansive spatio-temporal scales, as well as the state-building projects that both shape and are limited by them. Together they help conceptualize terrestrialization as a socionatural process rather than an evolutionary one, demonstrate how and why Vilkovchani's ability and desire to keep canals clear have waned, and show the consequences of an excess of silt.
If amphibious anthropology can serve as a framework for socialist and post-socialist transformation of delta life in Vilkovo by displacing the terracentrism of administrative and modern habits of thought, Vilkovchani's experiences of siltation and terrestrialization can be instructive in mapping an amphibious anthropology. There is a renewed interest in human habitation of deltas and wetlands because of the insights they provide into how to live with frequent inundation - that is, how to live with water-in conditions of climate change (Krause 2017; Krause 2018; Morita and Jensen 2017). But Vilkovchani remind us that 'the amphibious' should not be equated only with water and its flow. They show us that deltas involve processes of flow and sedimentation; river and delta dwellers may be as preoccupied with creating solid, dry places and with the problems created when channels dry out or fill in with silt as they are with flowing water (Richardson 2016; Scaramelli 2018a and 2018b). Though not an ethnography of tourist practices per se, this article aims to reveal the complex reasons for terrestrialization that are sometimes overlooked in efforts to develop the town's tourist potential. In doing so it also enlarges anthropological scholarship about human-environment relations in the Danube Delta. While anthropologists have examined fisheries, animal husbandry, the impact of tourism on village sociality, urban memory, and nature conservation mainly in the Romanian Delta (e.g. Bell 2001; Iorga 2016; Ivan 2017; Dorondel and Mitroi 2017; Tempeau and Van Assche 2015; Van Assche et al 2011), the ways in which contemporary delta dwellers grapple with the changing dynamics of flow and sedimentation-which is so consequential for human and nonhuman life particularly along the Danube's Kiliia Arm-have thus far received little attention. 
WHERE THE BROWN DANUBE MEETS THE BLACK SEA

The Danube is Europe's muddiest river, bringing 200 cubic kilometers of water and 35 million tons of sediments to the delta each year (Mikhailov et al. 2004: 59, 227). As the Black Sea has minimal tides, the Danube Delta has both fluvial-influenced and wave-influenced lobes (Giosan et al. 2005: 395). Vilkovo is located at the edge of the Kiliia Delta (the youngest of several lobes comprising the larger Danube Delta), which began forming roughly 350 years ago when the Kiliia arm broke through what is now called the Zhebrian sand ridge (Loczy 2007: 254). This wave-influenced marine delta is distinguished by species-rich reed beds, called plavni in Russian and zaplavy in Ukrainian, which have an island-like shape and are under water for several months of the year save for narrow bands along their edges (Mikhailova and Levashova 2001). Winds have a major impact on surge phenomena in the delta, bar formation at the mouth, and the intrusion of seawater into delta distributaries (Mikhailov et al. 2004: 24).

The first urban settlements appeared at the mouths of the Danube during the period of Greek colonization some two and a half thousand years ago when the river was known as Istria. Since then fishing, trade, and shipping have been the foundation of livelihoods in towns such as Istria, Halmyris, Isaccea, Licostomon (contemporary Kiliia), and later Tulcea, Izmail, Sulina, Galati, and Vilkovo, even as the encompassing states and trading priorities have changed (Poltorak 2016: 177). While towns competed with one another, they developed in similar conditions and residents learned ways of dwelling and building in the delta from one another (ibid.). For example, the similarity between a description of Kiliia in the Middle
Ages-featuring yeriki, wooden bridges and the checkerboard form of its streets and blocksand contemporary Vilkovo provides evidence of the transfer of elements of town-building from an ancient urban settlement to a new one (ibid.).

The Ukrainian Cossacks and Russian Old Believers who arrived in the mid 1700s, shortly after the Kiliia Delta began to form, settled in this sparsely populated frontier at the Ottoman Empire's northern edge in order to escape persecution by the Russian state (Bassov 2008; Prigarin, 2010; Siliantieva-Skorobogatova et al 1996). While the ease with which abundant fish could be caught at the Danube's shallow mouth attracted human settlers to the place that became Vilkovo (Prigarin 2015), it was the river's high sediment load and the rapidly growing plavni that enabled more and more of them to take up permanent residence. In the first decades, construction occurred in an unplanned way as people settled in distinct Ukrainian and Russian Old Believer areas along three axes: the bank of the Kiliia branch, the Guseva Canal (now known as Belgorod Canal), and a road that ran in the direction of the village of Zhebrian (now known as Prymorske) along the sand ridge (Poltorak 2016). Because land was in short supply, wood-framed silt-andreed houses were built close to one another and consequently residents suffered frequent fires in addition to frequent flooding (Dushakova 2013: 24). In 1848, the Russian Government commissioned the architect Illia Dombrovskii to create a town plan for Vilkovo, the goal of which was to 'divide sections equally among townspeople'. (Vilkovo became part of the Russian Empire in 1812 and in 1840 received the designation of town posad which came with additional self-governing rights.) Dombrovskii drew upon the existing 'checkerboard' layout but straightened some of the canals while allocating plots and creating canals in a way to localize 
those that posted a greater fire hazard (ibid.: 179). In the 1870 s, settlement expanded to Kilimbeika Island, and later to other islands in the Kiliia Delta where residents began to create orchards and gardens (Richardson 2015a).

The delta's opaque (to humans) ecologies at the edge of the Ottoman state made it an ideal refuge for people fleeing the state, similar to the circumstances in which Venice- the most iconic 'city on water-emerged, and the marshes and peat bogs that gave rise to Vilkovo's sister city, the Dutch town of Giethoorn (Lambert 1971: 108; Norwich 1982: 6). However, as the geopolitical significance of the river's navigational potential grew in the $19^{\text {th }}$ century, the area became a zone of conflict and tension as the Russian Empire, the Ottoman Empire, Romania, and other European powers vied for control over land and navigation on the Danube River. In the $20^{\text {th }}$ century alone Vilkovo was part of the Russian Imperial, Romanian, Soviet, and Ukrainian states, while today the Danube's Kiliia branch-one of the Danube Delta's three main distributaries-forms the international border between Ukraine and Romania and since 2007 between EU and non-EU states. ${ }^{6}$

Infrastructure built along the Danube and in its delta over the past 150 years has played a significant if indeterminate part in terrestrializing amphibious life along the Danube's Kiliia Branch. The straightening of the Sulina and Sf. Gheorghe branches (currently in Romania) to improve navigation in the delta has reduced the proportion of water flowing through the Kiliia Branch from 70\% to 49\% (Maffii et al. 2016: 22). The construction of the Iron Gates dams, built in the 1980s by Yugoslavia's socialist government, reduced the river's discharge including its sediment load, which has slowed the extension of the delta into the Black Sea (Mikhailov et al. 2004: 8). Meanwhile, in the postwar period Soviet authorities undertook the construction of domestic water supply, roads, several large enterprises, a sand quarry, and a port, which significantly altered the hydrology of the town's canal system. ${ }^{7}$ However, while some areas of the town, with private houses and Soviet-era apartment blocks, are located on terra firma and have no canal access, a significant part of the 'old town' (staryi gorod) - the key focus of this paper-is only accessible along the wooden sidewalks (po kladkam) or by boat (Figure 2).

Since the end of socialism, all enterprises have closed, and the town's population fell from 11,022 in 1989 to 9,260 in 2001, though town administrators and residents estimate that it is much lower as young people migrate and the elderly pass on. The designation of the Kiliia Delta as the Ramsar Wetland of international significance in 1995, and the transformation of a Soviet-era Dunaiskii Plavni zapovidnyk into the Danube Biosphere Reserve (DBR), reprioritized the delta as a refuge for nonhuman species (birds, insects, plants) (Figure 3). Although many Vilkovchani question the value of the DBR's existence because of restrictions on access to the reserve's core zone, the DBR has contributed to the town's ability to market itself as tourist destination (Van Assche et al 2011; Voloshkevych and Fedorenko 2005). While Vilkovchani born in the 1920s and thirties recall tourists visiting in the prewar period, Vilkovo was a closed border town from the late 1960s until the end of socialism in 1991 during which time special passes were required to enter.

Administrative support for tourism at the regional and national level has been inconsistent over the past 25 years. In the early 2000s, the government aimed to boost the regional economy through constructing an international shipping lane in the core zone of the DBR, paying little attention to the impact this would have on sensitive ecologies or tourism development. However, the Bystre Canal failed 


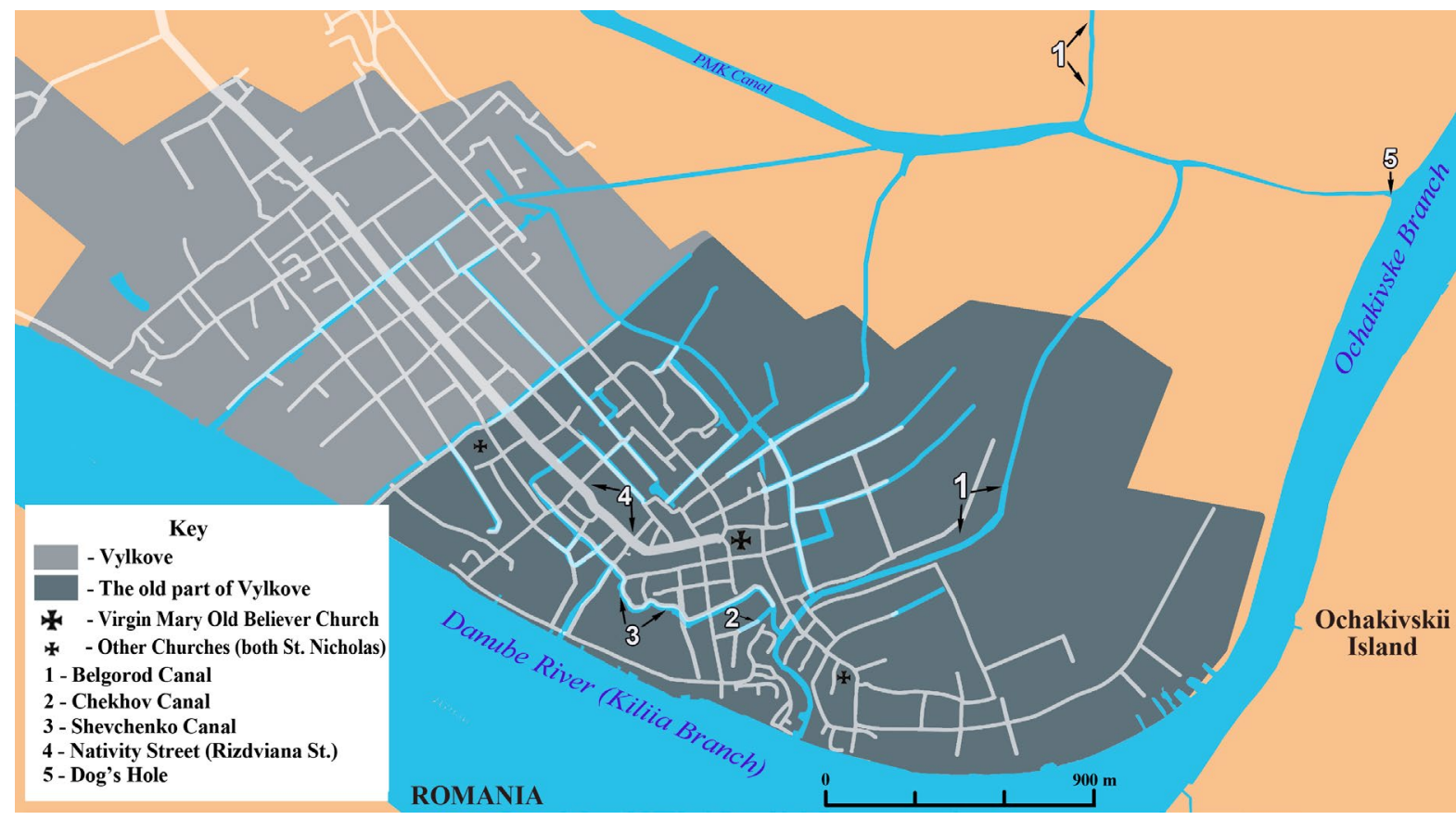

Figure 2: Map of Vilkovo. By Iryna Iakovlieva.

to create the 'thousands of jobs' promised or offer viable competition to Romania's Sulina Canal (Fedorenko 2006; Richardson 2015b). Since then, there is growing consensus between regional and town administrators that tourism development should be prioritized because it has the potential to lift Vilkovo's economic fortunes and the depressed Danube region as a whole (Anonymous author 2015). The Odesa Oblast Administration received a 4 million euro grant to install a new sewage system in a section of the old town, not only to reduce the current discharge of effluent, but also in view of an expected increase in tourists. The tourist agenda received a boost during the turbulent period in post-Maidan Ukraine when former Georgian President Mikheil Saakashvili served as head of the Odesa Oblast Administration (May 2015-November 2016). He secured funding for a major (albeit incomplete) renovation of the Odesa-Reni highway including the side road to Vilkovo that resulted in a 30\% increase in the number of tourists between 2016 and $2017 .{ }^{8}$
The increased siltation of the canals poses both economic and ecological problems for Vilkovo. While the loss of canals suitable for boat tours in Vilkovo may eventually deter tourists, small-scale individual entrepreneurs could be affected even before this happens as their access to tourists is reduced. In contrast to two larger firms that own multiple boats (including some that can hold 50 people) and can take tourists into the Reserve territories because they are officially registered businesses, residents who make money informally are more reliant on the town's canals because they have neither the permits nor appropriate boats to take tourists further afield. The in-filling of canals can also accelerate salinization of land. Consequently, the siltation of canals is not only a concern for the 20-30 small-scale individual entrepreneurs, but also for the far greater number of residents who rely on gardens for subsistence and market-oriented crops. 


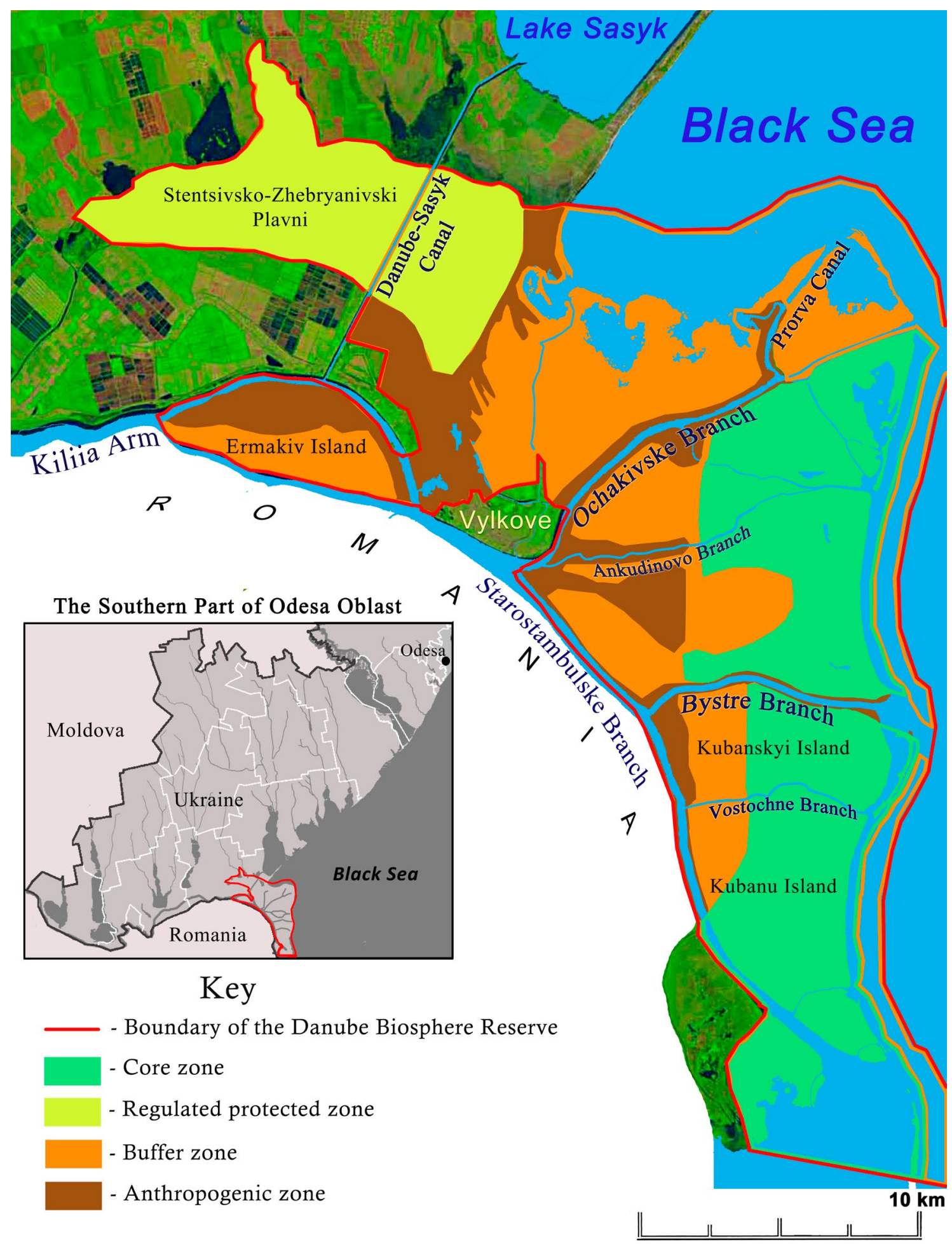

Figure 3: Map of the Danube Biosphere Reserve and the Kiliia Delta. 


\section{AMPHIBIOUS ANTHROPOLOGY IN A TERRESTRIALIZING PLACE}

For centuries, marshes, swamps, floodplains and deltas around the world-including those in the Russian Empire and the Soviet Union-were reclaimed, drained, and dredged while their inhabitants and ways of life were displaced (Blackbourn 2006; Bruisch 2018). The globally circulating term 'wetland' gathers together a diverse range of places such as fens, bogs, marshes, lagoons, and estuaries (Giblett 1996; Grupposo 2017; Matthews 1993: 1, 6; Scaramelli 2018a: 408, 410-12). While scientists have advocated the protection of wetlands on account of their biodiversity for more than half a century, more recently architects and engineers have turned their attention to human habitation of wetlands for insight into how to live with climate-change induced inundation. ${ }^{9}$ Anthropologists (and geographers) have also turned their attention to these places not only because of their importance for conservation and coastal protection projects and their vulnerability to flooding as a consequence of climate change (e.g. Cons 2018; Jensen 2017; Morita 2016; Khan 2014; Krause 2017; Scaramelli 2018b), but also for the ways in which the forms of life they support help unthink the premises of modern epistemologies such as the nature/culture and land/water divides that led to the destruction of wetlands in the first place (McLean 2011; Lahiri-Dutt 2014).

'Amphibious' is one such word scholars are mobilizing to conceptualize human life in wet places (Gagné and Rasmussen 2016; Jensen 2017; Krause 2017; Pauwelussen and Verschoor 2017). While humans are a terrestrial rather than amphibious species from the point of view of evolutionary biology (ten Bos 2009), architects, engineers, planners, anthropologists, and (more insidiously) military strategists are increasingly using 'the amphibious' to describe architectural, design, engineering, and dwelling strategies that enable humans to inhabit or traverse wet or muddy places, and sometimes muddy environments themselves. Programmatic statements about amphibious anthropology are informed by literatures on place, space, and landscape as well as literatures about water and infrastructure that are attentive to the ways in which water's materiality and multiplicity are entangled with and constitutive of human worlds (Feaux de la Croix 2011 and 2014; Helmreich 2011; Krause 2014; Anand 2011; Barnes and Alatout 2012; Strang 2005; Krause and Strang 2016; Hastrup and Hastrup 2016). Literature about place and landscape offers a way to get beyond land/water binaries by homing in on the ways in which people describe and dwell in wet environments (Basso 1996; Ingold 2000). Hugh Raffles and Stuart McLean produce accounts of the Amazonian floodplain and European swamps whose material poetics of porosity, viscosity, and flux pushes beyond the constraints of the land/water binary (McLean 2011; Raffles 2002). During my own fieldwork, gardeners and fishermen rarely spoke of 'the delta' and even less frequently of 'wetlands' (Rus. vodobolotnaia uggodia). They spoke instead of kinds of places (the sea, the river, the reed marshes [plavni], the islands, lakes, bays, the town, yerik), named places (Bird's Spit, Salty Bay, Dog's Hole, etc. see Siliantieva-Skorobogatova 1996: 156-69), and the physical labor required to maintain them, in terms similar to those Hugh Raffles describes in the Amazonian floodplain (2002: 27, 64). Because my Russian-speaking informants used plavni as a general term for the surroundings and sometimes referred to themselves as 'people of the plavni I will use the Russian word plavni from here on in without translation. 
The anthropological literature on water is helpful for conceptualizing people's relations with flowing substances in deltas and wetlands and countering entrenched terracentric habits of thought. For example, Gagné and Rasmussen describe their version of amphibious anthropology variously as the study of 'the production of place at the confluence of land and water', the 'relational ontology between land and water in the production of place', and 'how the boundaries between land and water intermingle' (2016: 136). Jensen mobilizes 'the amphibious' to characterize a relationship to water, water infrastructure, and water management that 'takes water flows as given and organizes life around it' in contrast to 'terrestrial responses that centre on land reclamation, drainage and defence' (2017: 225; see also Morita 2016). Pauwelussen and Verschoor use it to refer to 'the ability to move in and relate to different worlds that do not add up, yet partly flow into each other', and to positively value ambiguity (2017: 295). Krause's (2017) conceptual and methodological for framework for studying delta life anthropologically calls for centring hydrosociality along with volatility, wetness, and pulsing rhythms.

However, privileging water (recentring it) in conceptualizing the amphibious-a strategy adopted to challenge terracentrism of modern social theory-can also in advertently reinforce the land/water binary, the notion that land and water are pre-existing, distinct or 'normal' states of being. This is evident in the notions that a relation can be established between a (pre-existing) substance of land and water (e.g. Gagné and Rasmussen 2016) and that a hybrid (mud; land-sea) exists or can be created (e.g. Pauwelussen and Verschoor 2017: 295; Lahiri-Dutt 2014); and in the contrast between 'terrestrial' and 'amphibious' infrastructure (Jensen 2017; Morita 2016). Krause’s centring of bydrosociality and wetness conceptually still privileges water and wetness (Krause 2017: 405-6). Privileging water makes it hard to grasp Vilkovchani's perceptions of their surroundings, which we might summarize as in the beginning there was mud', and their contemporary predicaments of siltation. Nevertheless, Krause's emphasis on flux and reference to other-thanliquid states of matter (mud and ice) can be used to direct attention to how a separations are made, and what the consequences are when people's valuation of wet and dry, liquid and solid changes.

I use the term terrestrialization to describe the confluence of geomorphological, ecological and social dimensions of landscape change in Vilkovo. Terrestrialization is typically used by wetland ecologists to describe a process through which bodies of open water fill with organic or inorganic matter that transforms open water to a land plant community (Tiner 2017: 80-81). In scientific studies of evolution, it can also refer to the geological process of creating land itself (e.g. through volcanic action) and the adaptive processes through which an aquatic organism (plant or animal) comes to inhabit land, including the process of aerialization (Janvier 2010: 9). I use terrestrialization to name a socionatural process in which changes in the hydrology and sediment regime of the lower Danube (partly the result of human intervention such as dams and straightened river channels) both intensifies and is intensified by political economic changes that have reduced people's reliance on canals for freshwater and led them to turn away from river-based livelihoods.

Terrestrialization lends itself to thinking about Vilkovo's changing townscape better than land reclamation, another way these changes might be framed. Some of Vilkovchani's actions do resemble acts of land reclamation in urban and rural settings in different times and places, 
such as the Rijnland between the $11^{\text {th }}$ and $13^{\text {th }}$ centuries when settlers inhabiting sand dunes made peat bogs inhabitable by constructing dams, dikes, canals or sluices (Lambert 1971: 108; TeBrake 1985: 14). However, land reclamation in the Netherlands and elsewhere in Europe was done with the goal of creating land for pasturing or farming which then became the foundation of people's livelihoods. By contrast, for most of Vilkovo's existence, its residents' livelihoods centred on fisheries and have been oriented to the river. In that sense Vilkovo did resemble Venice in the $6^{\text {th }}$ century (Norwich 1982: 6). While large-scale, state-sponsored land reclamation projects were pursued in both the Soviet Ukrainian and Romanian parts of the delta, the terrain around Vilkovo was too inundated and too vulnerable to flooding to make large-scale reclamation worthwhile. Finally, while deliberate acts of filling in canals to make roads in Vilkovo do resemble other contemporary urban contexts (Hudson 1996; Padawangi and Douglass 2015), the siltation occurring in Vilkovo's canals is also partly the consequence of abandonment and thus does not only involve deliberate acts of in-filling.

This ethnographic portrait of terrestrialization also engages with recent anthropological scholarship at the interface between STS and political ecology that emphasizes the significance of infrastructure in understanding how landscapes acquire a given (taken-forgranted) form, and the distribution of benefits and harms that occur as part of that (Barnes 2014; Carse 2014; Blok et al 2016; Morita 2016: 118). With respect to river deltas, Morita and Jensen's broad programmatic statement claims that infrastructure and cosmology are central for understanding the kinds of places deltas come to be. A massive flood in 2011 in Thailand's Chao Phraya Delta was a critical event that made visible the palimpsest of 'Western' and 'premodern southeast Asian' infrastructures in the area. Following these discussions, they argue that 'Western' water management is 'terrestrial' in that its infrastructure projects are built to extend land into the sea while premodern amphibious or aquatic 'southeast Asian' infrastructures were built to extend the sea into the land.

This broad framing is helpful in drawing attention to infrastructural palimpsests. However, it is complicated when the focus is dwelling practices in a particular settlementVilkovo-with its history as part of the Soviet Union. First, drawing a sharp contrast between modern 'terrestrial' and traditional 'amphibious' or 'aquatic' infrastructure misses what is distinctive about Vilkovo's canal system: its fluctuation between aquatic and terrestrial states over the course of the year. Second, the West/non-West binary is unhelpful in grasping the superimposition of different infrastructures on top of one another in a postSoviet setting. Medium and large socialist cities did experience something approaching the universality norm typical for similarsized cities in Europe and North America (the Global North) for electricity, heating, gas, sewage and water provision (Chelcea and Pulay 2015). However, in smaller towns such as Vilkovo we find infrastructural palimpsests where modern $20^{\text {th }}$-century road and watersupply infrastructures were super-imposed on a multi-purpose, hand-dug canal system created in the $18^{\text {th }}$ and $19^{\text {th }}$ centuries (both of which are 'Western') producing effects not unlike what Furlong describes as the norm in the Global South (Furlong 2014: 140). By providing an ethnographic description of Vilkovchani's dwelling practices and how they have changed as a result of the encounter with Soviet modernity and post-Soviet deindustrialization, this paper makes the case for treating terrestrialization ethnographically in particular locales rather 
than as something that is known and classifiable as the product of 'Western' infrastructure.

\section{THE MUDDY MATTERS OF DWELLING IN THE PLAVNI}

Vilkovchani's narratives of place often begin with flight from elsewhere, emphasize the plavni as a place of refuge, and then turn to the act of settling (cf. Prigarin 2010: 420). ${ }^{10}$ Statements such as 'We conquered (otvoievali) this land from the sea and the plavni' enact Enlightenment land/water and culture/nature oppositions similar to settlers of other frontiers (Blackbourn 2006; Raffles 2002). Yet, when closely observed, residents' practices of making and maintaining gardens, canals, and homes appear to be more like processes 'wherein people and their environments are continually bringing each other into being' (Ingold 2000: 87) and thus do not completely align with the Enlightenment narratives they cite.

I begin, as Vilkovchani do, with labor: Kopali. Nabrosali. Namostili. 'We dug. We threw on [the mud]. We built up [a plot].' Residents recited these three verbs over and over again as they described the 'physical corporeal action' of transforming the plavni to make it habitable by literally creating islands of solidity (Raffles 2002: 61). Townspeople regularly stress to outsiders the fact that their plots, canals, houses and kladki are 'handmade' (rukotvorno). Elderly Vilkovchani contrast the newness of the land they inhabit with 'land that has existed for eternity' in the nearby steppe. Silantieva-Skorobogatova, former resident and author, painted the following portrait of the environment that settlers encountered: 'There was no real land: small islands, mud, reeds-that's what their earth [zemnaia tverd] looked like' (Silantieva-Skorobogatova 1996: 25). Evdokiia Ivanova, an elderly Old Believer woman born in 1926, elaborated: 'Our parents told us that this was plavni. When they came, there were few houses and they were far apart from one another. People occupied a large area and made a place to live. Their children grew up and they then built up their own plot in the reeds (plavniu mostiut). Silt was deposited on dunes and in the canals. And we took the silt to our yards (dvor). ${ }^{11}$

Digging not only brought island-like plots into being, it also gave rise to yeriki. Until the early 1960s, yeriki (between two to eight meters wide and one to three meters deep), were a source of water for drinking, bathing, washing, fishing, fire protection, and watering gardens for all the town's residents and they continue to fulfill all these functions for roughly a third of the town today. If canals initially emerged out of efforts to solidify and liquify areas of plavni, as the delta expanded, and more people settled in Vilkovo, canals were cleared to secure access to the Danube's branches in order to fish, hunt, cut reeds and gather plants. While willow trees are planted to reinforce steeply slanting banks, the banks themselves are to be kept clear of weeds and reeds in order to ease the passage of the wooden boats and ensure access to water and silt. The back-breaking labour of clearing canals is a prominent theme as well, and techniques vary depending on when one clears them and how much water is in the canal. If it is shallow, one can stand in the yerik and grab an armful of mud and dump it on the bank. The key here, is to be able to keep your head above the level of the water. If the water is deeper, a special angular shovel shaped at the end of a long pole is used to scrap up the molten silt while standing on the bank. Finally, one can also dig the silt up with a flat spade-like shovel when the canals no longer have water in them.

Making land in the plavni is not a one-off event; residents of the Kiliia Delta experience 
firsthand, much like the dwellers of the Amazonian floodplain described by Raffles, how 'nature in its biophysicality is never in stasis, and forces a constant reinvestment and reinvention of labor, debate and knowledge' (Raffles 2002: 68). Floods may wash land away in one place and add to it in others. Gardens may become inaccessible because new shoals form. Floods also wash away gardens' fertile top layers of silt and leave hard packed earth in their wake. Anomalous flooding during a heat wave in July 2010 ruined many gardeners' strawberry plots and killed numerous trees; in mid-August purple plums hung uncannily on branches devoid of leaves, unable to ripen.

Given that the water table is practically at the surface, residents constantly battle water seepage in foundations and walls in high water years and the creeping mold that accompanies it (cf. Cons 2017). They pray to die in the fall so that they can be buried in dry earth rather than in mud. Even without flooding, land subsidence causes houses to shift and their walls to crack, as Nadia, the guide we met in the introduction, indicated. And so, every few years, residents in some parts of Vilkovo and owners of island gardens build up their plots with silt taken from the yeriki or transported from the shore of the Danube. Thus, while on the one hand, digging creates distinct zones of (relatively) solid, dry ground and running water, everyday life involves continuous acts of maintenance to induce and prevent the plavnis transformation from solid to liquid (e.g. during flooding) and liquid to solid (e.g. through sediment deposition).

Gardening on islands such as Ochakiv and Ankundinov exemplifies the subtleties of managing fluctuating processes of flow and deposition. Island garden plots must be created and maintained at the right height in relation to the level of the river, a task both tricky and important given that the garden may flood if it is too low or dry out if it is too high. Plots must also be enriched with silt every two years to remain fertile. But not just any silt (il) will do. It is the fresh silt from the annual deposition (namyv) that occurs during the high-water period that is most significant for enriching land. But just as floods differ from year to year, so too does the deposition of silt. Evdokiia explained: 'When the water was high in the spring, we'd look and say 'the water is yellow (zholtaia)-we'll have silt this year...' There are times when the water is 'light' (svetlaia). That means that there will be no silt.' Maintaining yeriki at the right depth is also important for gardeners because deep canals help plots retain moisture even when the water levels drop in summer and thus help keep fruit tree roots moist. Island gardeners regularly create small hills of silt around the trunk to hold moisture and during floods may dig zig-zagging canals around trees to create additional area for water to drain off and inflitrate the soil (Figure 4).

Like land and water, river and sea are also not radically separate and oppositional zones for Vilkovchani. Vilkovo is situated at one tip of the Zhebrian sand ridge. Although Vilkovo is now located 18 kilometers from the river mouth, the saltwater and sand of the Black Sea are still forceful presences in all townspeople's lives. Residents described how they struck hard packed sand with seashells when digging the foundation of their houses. Depending on the location, this might be because of their proximity to the Zhebrian sand ridge or because of the sandy foundations Dombrovskii required residents to make (cf. Poltorak 2016). The presence of salt-saturated sand beneath gardens means canals need to be deep enough to have fresh water in them to prevent salt from rising due to evaporation during the hot summers. While silt should be added to gardens each year as fertilizer, diggers must avoid throwing saltsaturated sand onto their plots. 


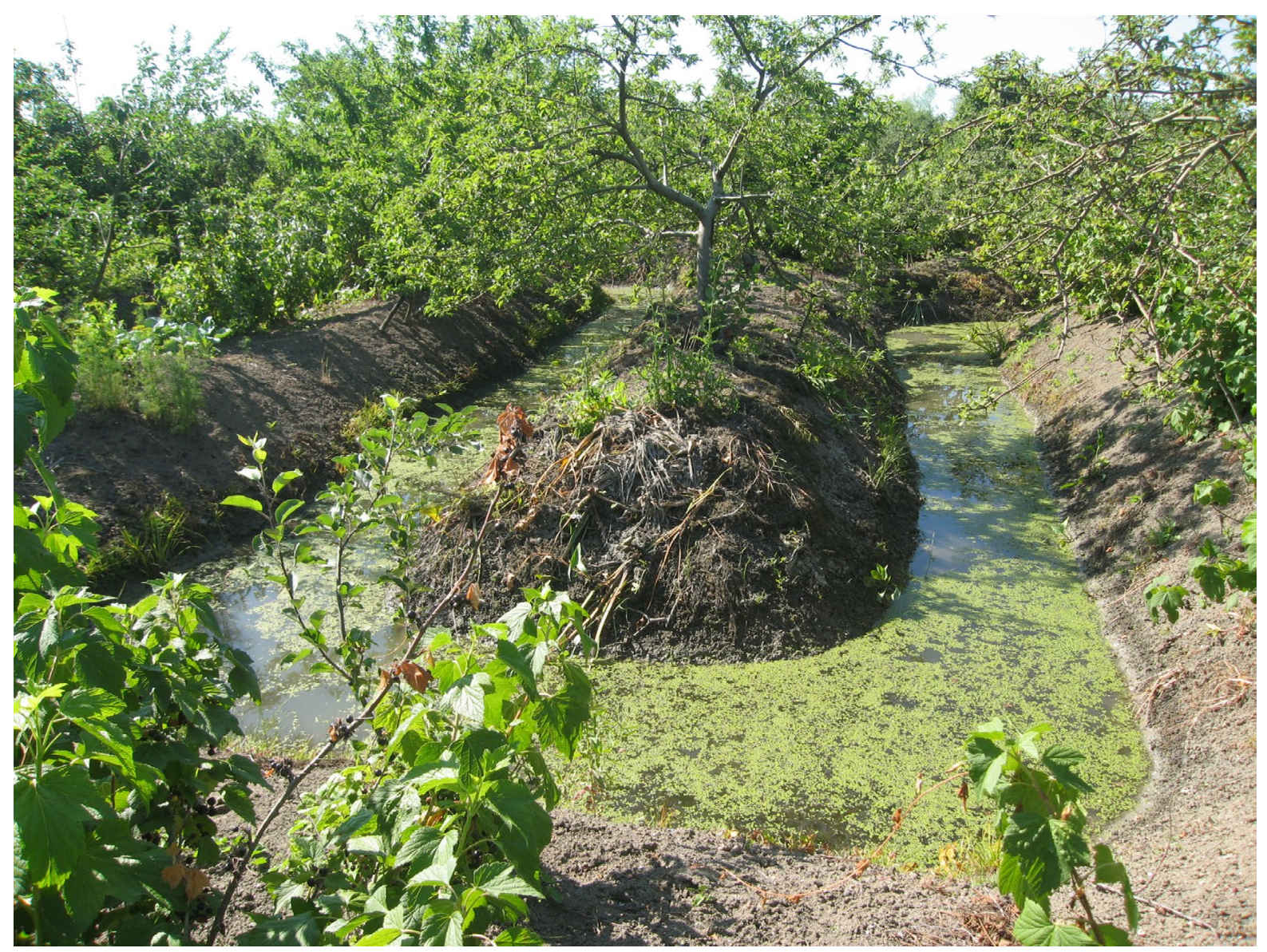

Figure 4: Photo of drainage canals on an Ochakiv Island Garden. Photo by Author.

Black Sea water is also a strong presence in residents' lives under certain winds. I was told that the first thing one should learn when living in Vilkovo is the local names of the winds and their significance because 'we are all dependent on the wind here'. ${ }^{12}$ An easterly wind is generally viewed positively-signalled in the phrase "we are waiting for weather from the sea'-because it facilitates the return of herring to the Kiliia branch to spawn. But an easterly wind can also mean harm when the river is in its high-water phase, particularly when there is ice. During surges, easterly winds press seawater up against discharging river water. This slows the discharge of river water and which can result in the river overflowing its banks, which is what happened in 1969 during the worst flood in living memory (Mikhailov et al. 2004: 183-8). But if the change to a westerly wind can save the town from a flood, in the fall it can create problems for people trying to get their boats from a small yerik to the Kiliia arm. When I asked an acquaintance about her island garden during a conversation at the market on September 7, 2012, she explained that she had not been able to get out because a westerly wind had lowered the water level in the river and canals preventing her from launching her boat (Figure 5).

While Vilkovchani's practices of making plots and digging canals seem to be a textbook case of what Ingold theorizes as 'dwelling', Vilkovchani's accounts remind us that this 


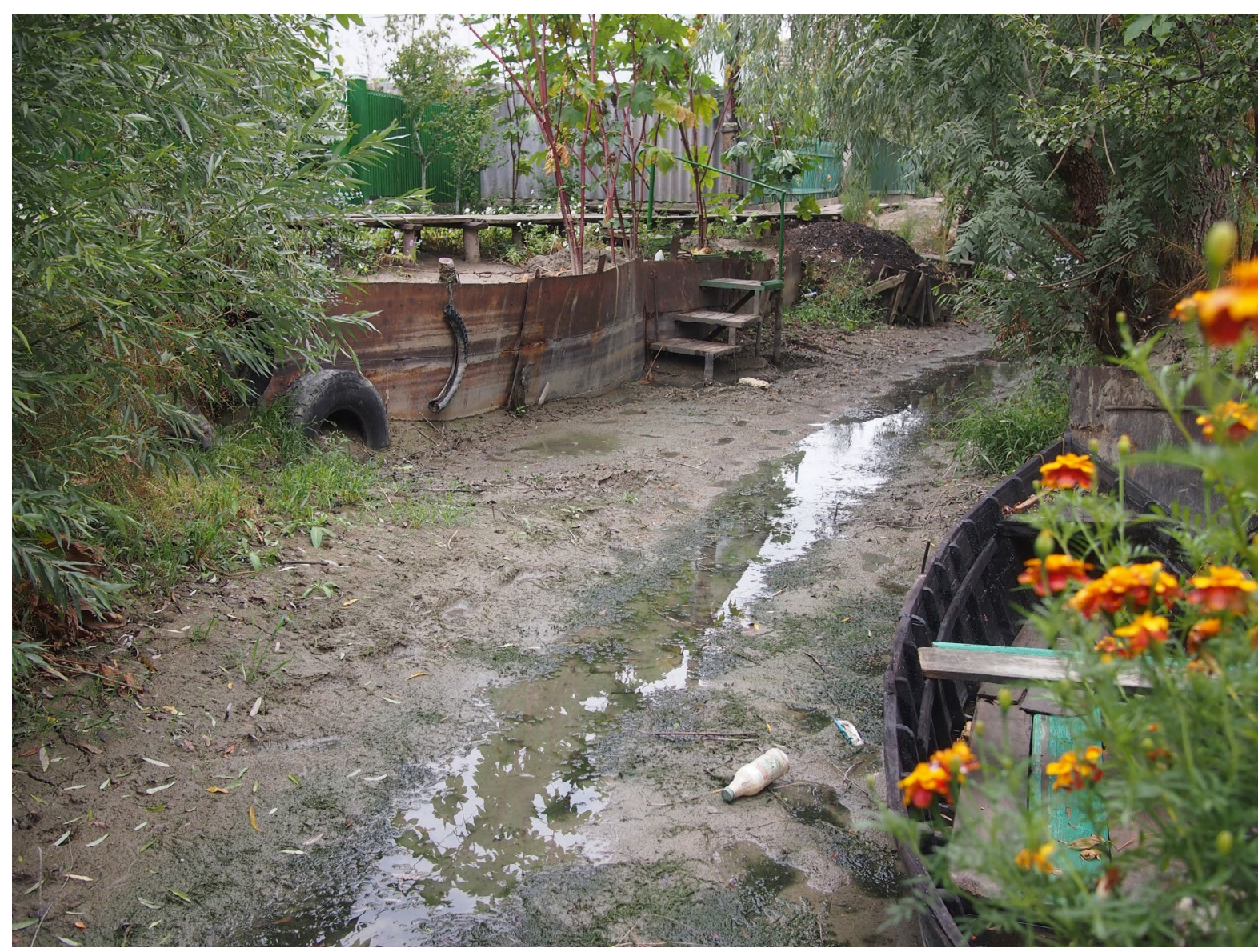

Figure 5: Photo of Gorkii Canal with no water during a westerly wind. It has been renamed Hrusherskii Canal as a result of Ukraine's 2015 decommunization laws. Photo by author.

does not mean that relationships are always harmonious. The movement and settlement of sediments could also generate division and dispute. Because silt was essential for constructing homes and making plots, and was neither deposited every year, nor in equal amounts in all yeriki, people sometimes fought over it. A reed was used to divide the yeriki in half between neighbors on opposite sides of the yerik so that no one took more than what belonged to them. Sometimes disputes came to blows if one person was felt to have taken more than their share. Aksinia Selezneva (born in 1925) explained that her yerik never received a deposition of fresh sediments (namyv) because it was a dead end. Therefore, she took silt from the nearest main yerik when she and her sister began building her house, a generally accepted practice. However, nearby residents disputed her claim and forced her to go to another large yerik for her building material.

These narratives and practices of settling and living in the plavni illuminate the forms of dwelling that enabled habitation of the fluctuating and unpredictable delta-lobein-formation. While visitors may perceive Vilkovo as 'organically' merged with the river, Vilkovchani's narratives reveal the tremendous amount of labor required to maintain their homes and their canals. In contrast to modern 
infrastructures in the developed world where the labor of construction and maintenance is often concealed (Graham and Thrift 2007: 8), in the case of the yeriki these are key components of people's narratives and sense of place. In spite of the absence of amphibious architecture in Vilkovo, characteristic of other deltas, ${ }^{13}$ the multiplicity of acts plavni dwellers undertake to encourage and constrain the delta's fluctuations is instructive in mapping a concept of the amphibious. While Vilkovchani's narratives sometimes enact land/water separation, their practices of making and maintaining their homes and canals were based on the assumption that one could not take for granted the existence of a space as either land or water. Finally, for much of the town's existence, townspeople's practices do not seem to have been based on a categorical valuation of land over water or liquid over solid (or vice versa). Indeed, 'There needs to be water!' was the phrase Aksinia Selezneva recited when she recalled her mother's distress at witnessing the reclamation of canals around the Virgin Mary Old Believer church. It is to processes leading to the canals' siltation and in-filling that I now turn.

\section{PO MATERNOMU-OR, TERRESTRIALIZING RIVER RELATIONS}

'By the time you finish writing your book about Vilkovo, the water arteries of this townyeriki-will no longer exist,' stated Nikolai Izotov, a witty, philosophical Old Believer who provides boat excursions to tourists for which he received an award in (Figure 6). He made cleaning canals a key electoral issue when he worked as campaign manager during the mayoral elections in Vilkovo in 2005 after Ukraine's Orange Revolution (his candidate came second). Though the canals' condition is a sore spot for Nikolai, others, including Nikolai's business partner Vladimir, responded to my questions by asking: 'Who needs yeriki?' Commenting on the canals' sorry state in May 2011, Nikolai offered the following explanation: 'My s rekoi ne na $V y$, ne na ty, a tolko po maternomu.' (We are no longer on formal [You/Vy] or friendly [you/ty] terms with the river; we only swear at it). Elaborating in a follow up conversation in August 2013 he said,

To relate to the river as $V y$ is to treat her ${ }^{14}$ with respect like a mother or a grandmother. And to relate to the river as a ty-that's like 'come on, come on, let's dig, let's throw the silt.'You know, to relate to the river a little as a natural resource but not like extracting oil. But we should relate to the river as $V y$. We should respect and fear her.

Political ecologists have produced incisive accounts of how the 'circulation of water, food, cars, fumes, money, labor (...) transform the city and produce the urban as a continuously changing socio-ecological landscape' (Swyngedouw 2005: 21). While political ecological accounts of urban life have so far focused on capitalist environments, its key insights may be used to consider how the overlay of modern infrastructures on top of the canal system modified Vilkovchani's relationships with water and mud in ways that have terrestrialized their lives and their townscape. The construction of water pipes and tap water brought what Jamie Linton calls 'modern water' into being in the Kiliia Delta (Linton 2010). In Vilkovo, similar to rural Kyrgyzstan and Rio de Janeiro, 'modern water' has not entirely displaced other waters (Feaux de la Croix 2016; Kane 2012: 62). One third of the town does not have piped water and most homes have septic tanks or outhouses. ${ }^{15}$ 


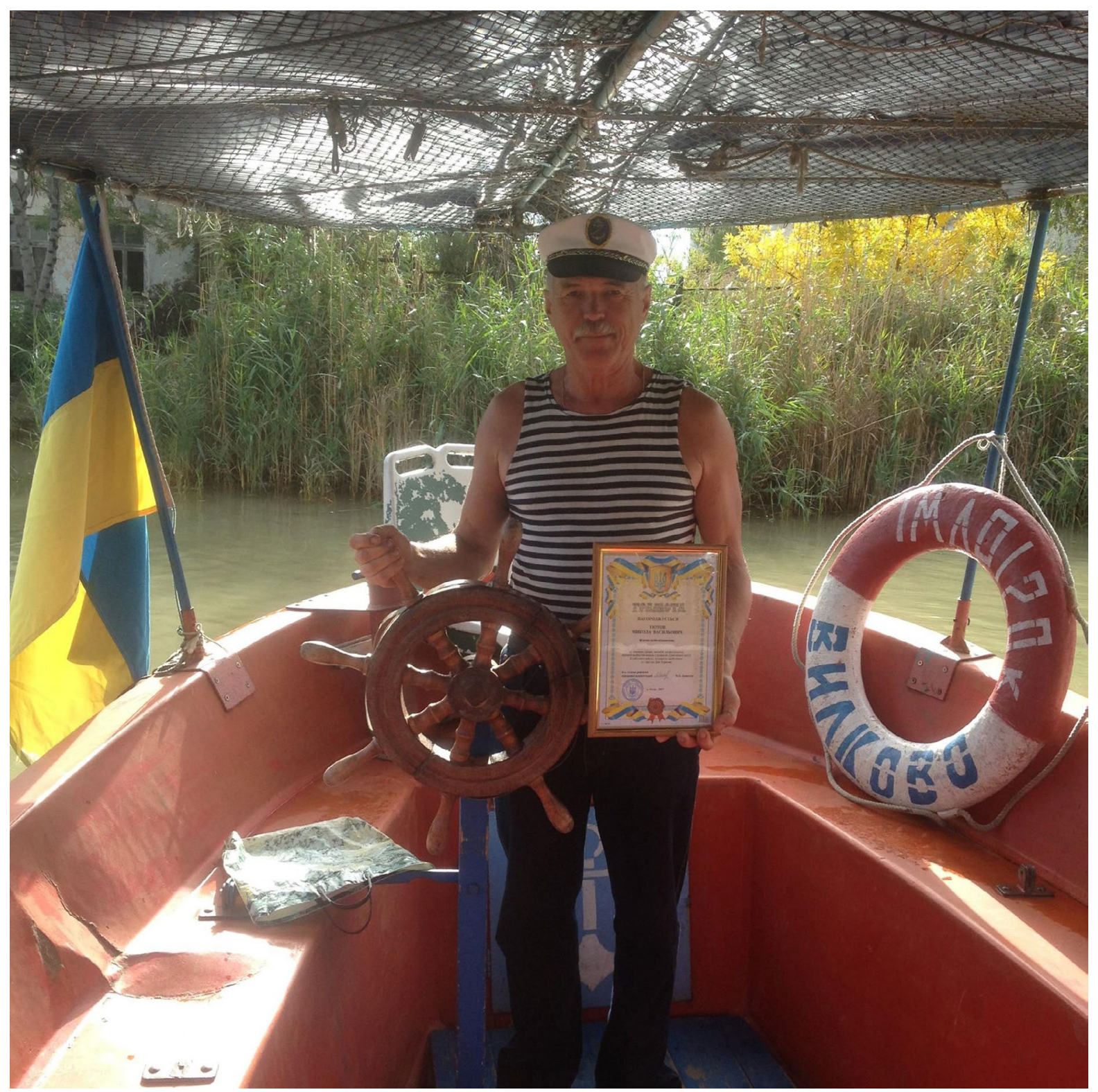

Figure 6: Photo of Nikolai Izotov after receiving his award. Photo by Vladimir Khomutov.

However, the introduction of pipes created blockages (stagnant and sedimenting canals) that have accelerated the infilling of the canal system. The town's terrestrialization is now seen by Nikolai and other entrepreneurs and administrators as hindering other kinds of flows, such as tourists and their money.

Conversations with long-term residents of Vilkovo between the ages of 50 and 80 suggest that besides roads, two water infrastructure projects in particular-water pipes and the dredging of a large artificial canal for extracting sand-were key in rearranging everyday relationships with water and sediments in ways that intensified the in-filling and siltation of the yeriki. While Stephen Collier argues that heating infrastructure is most significant for understanding the physical form of small 
Soviet-built industrial cities in Russia, in Vilkovo, roads and the supply of piped water infrastructure are more important (Collier 2004). ${ }^{16}$ Until the 1960s, the yeriki were a source of water for drinking and washing clothes. When the water was flowing, residents took water from their yeriki; when it was stagnant, they brought water in pails from the Belgorod, Kiliia or Ochakov branches of the Danube. However, according to Evkokiia's husband, Tikhon Ivanov (b. 1924), when the water supply system was built in the 1960s and extended in the 1970s, smaller canals were filled during the construction process. A conversation with my landlady, Anna Khramova (b. 1951), who is also a Russian Old Believer, illustrates townspeople's changing relationships with the canals. As I helped her plant tomatoes one night, she berated herself to her next-door neighbor for planting them so late with this idiom: ' $U$ nas budet urozhai kogda po yerike poplyout' (We will harvest when others' scraps are floating in the yeriki). Later she elaborated, 'Before, people did not throw their cuttings and waste into the yeriki because we drank from them. That expression shows how things have changed.'

Whereas the construction of water pipes involved turning yeriki into solid ground, in the $1980 \mathrm{~s}$ excavators dredged a 10 meter-wide, 3.5-kilometer-long artificial canal through the town so that barges could transport quarried sand to construction sites up-river. In dredging the canal (called the $\mathrm{PMK}^{17}$ canal), the Vilkovobased branch of the Danube-Dnister Irrigation System (PMK) cut a hole through Kilimbeika Island thereby turning patches of plavni into an unambiguously aquatic space. The holecalled 'Dog's Hole'-became a convenient shortcut for residents, particularly fishermen ${ }^{18}$ (see Figure 2). However, after the cut was made some gardeners abandoned plots along a stretch of Belgorod because of the reduced annual silt deposition and availability of water in the plavni. Volodymyr Ehorashchenko, an engineer involved in preparing the project to clean the canals for the town council in 1992, described the changes thus:

\begin{abstract}
The gradient of a river channel determines the speed of water. The speed of water determines the degree of siltation. When they cut open the Dog's Hole, they reduced the gradient on the part of the Belgorod Channel that feeds the town's canals. Less water flows into Belgorod and more follows along the Kiliia branch and into the Dog's Hole, bypassing Belgorod. As a result, there is reduced flow in Belgorod and increased siltation.
\end{abstract}

While the PMK canal created economic opportunity for the enterprise and inadvertently for fishermen, its modification of the hydrology of the Belgorod Channel reduced sediment deposition where it was desired and increased it where it was not.

Vilkovchani's constitution as socialist subjects through schools, work, and consumption also changed some residents' practices of engaging with water and mud, their concerns with flow and sedimentation, and the centrality of the river and Vilkovo's canals in their livelihoods. In contrast to earlier periods when most men fished, in the Soviet Union, fathers encouraged sons to take up better paid, more prestigious, and less physically demanding work in other professions. ${ }^{19}$ By the late 1980s, besides the Cannery and the Fishing Collective, work was available in the Ust-Dunaisk Port, the Press factory, a branch of the Irrigation Infrastructure Production Enterprise, the Ship Repair Enterprise, a rehabilitation centre for alcoholics, and two schools, clinics, the hospital, the town administration, and other enterprises 
(Bassov 2008). Nikolai explained the impact of these employment opportunities on his family and his valuation of his island garden during a conversation in his kitchen in May 2011:

I had a large plot on the islands. I worked in the Ship Repair Enterprise. Then I worked in a car repair enterprise. My wife worked as the senior technician of the repair section that made kladki [raised wooden sidewalks]. Why did we need the garden? I got paid 200 rubles, my wife 150. It was enough. We needed some land to grow grapes for wine. So, we sold one plot. Then another.

The purchase of cars also had an impact. The number of roads grew dramatically between the 1960s and 80s. Townspeople also built roads. Nikolai explained: 'We filled in this yerik because I bought a car. This lane [50 meters] that runs to the clinic used to be a yerik. Bit by bit, I filled it in right up here to the garage. So, I too, am a sinner.'

The dramatic changes to the production process after socialism and new forms of governance have also intensified the accumulation of sediments in the canals. Limited employment opportunities have produced a shrinking, aging population. Some households lack the labor capacity to dig up yeriki because the elderly live alone and their children have moved to other towns. Fewer and fewer men fish because of high up-front cost of equipment and declining fish stocks. Many gardeners have abandoned their plots on the islands and sold their boats because of the increased cost of agricultural inputs (including gas for boats) and the difficulties of getting their produce to market now that river and sea passenger ships to Izmail and Odesa no longer operate (Richardson 2015a). Nikolai elaborates:
People have cooled off towards the river. Only half the people working on the river [fishing] are Vilkovchani. The other half comes from Kiliia, Liski, and Prymorsk'e [other towns and villages in the district]. This is because sometimes there are herring and sometimes there aren't. Sometimes the quota is small and so there are fish but they can't catch them. So people have begun to leave. Younger men sail on foreign container ships. Older men go and work in construction in Moscow and Petersburg. Women go to work in casinos in Czech Republic, Poland, or Bulgaria. Because they've left, they don't need yeriki. (...) Old people don't need them either.

Democratic forms of government and new environmental regulation have also played a part in the infilling of canals. Coercive measures used in Romania (beatings) and the Soviet Union (withholding fishing passes) to force residents to dig up canals are no longer available. While fiscal constraints and standardized budgets create financial obstacles to cleaning the canals (e.g., no budget line for cleaning canals), new environmental regulation makes it difficult to use funds when they are available. During an interview on September 17,2012, deputy mayor Ivan Soloviev described how he spent a year gathering documentation in order to use money the State Enterprise Delta Lotsman provided the town to clean the Belgorod Channel. Because the canal is regulated by the Water Code (1995), documentation from numerous agencies (Land Department, Ecological Inspection, Fishing Committee, Sanitary-Epidemiological Service) was required to demonstrate that dredging would not harm plant and animal life, and that the dredged materials are not contaminated. Since 2012, when the state has provided funding, it has often been insufficient (Anonymous author 2017). 
However, even money and permits are no guarantee that the dredging process will go smoothly. Many residents have extended their banks for gardens or built garages and claim ownership of them even though the banks officially belong to the city. The owner of a local firm hired to do the dredging work on the Belgorod Channel described in the introduction, explained that while some residents may support cleaning canals, others object and 'create scandals' because they have to move the earth excavators dump on their bank, because they have no place to put the slurry, or because the process causes houses to shift and walls to crack. One resident even sued the city administration for damage caused to his house.

Moreover, the town council twice rejected projects to clean all major arteries: once in 1992 and once during the World Bank Project that created the Danube Biosphere Reserve. Both projects envisioned the closure of Dog's Hole to prevent accelerated siltation and make the cleaning financially worthwhile. Because of this, a contingent of 150 residents-many of them fishermen-successfully lobbied the mayor and city council to stop these projects. While some objected to having to remove their garages, for others the key issue was keeping Dog's Hole open because it makes it easier to get illegally caught fish back to their homes.

Vilkovo escaped the fate of being turned into solid land in the1960s, thanks to a land reclamation plan left unrealized in one of the town's enterprises (Poltorak 2016: 181). However, the construction of other modern infrastructure and new forms of production and consumption into which Vilkovchani were drawn changed people's relationship with the canals, the river, and the plavni in ways that have terrestrialized livelihoods and the townscape. Conflicts arising out of town administrators' efforts to clear the canals vividly reveal not only the economic and technical challenges involved (e.g., lack of funds, regulation, dredgers damaging homes), but also the way in which more and more residents align with the town's terra firma over its waterways. 'Po maternomu' (we swear at the river) encapsulates Nikolai's critique of how the political ecologies of socialism and post-socialism have made Vilkovchani indifferent or opposed to maintaining intricate and fluctuating relationships between water and land along the Danube's Kiliia branch that sustained an amphibious way of life. While some men do continue to live amphibious lives, they are oceanic rather than fluvial in that they involve work on foreign-owned commercial cargo ships.

\section{CONCLUSION}

'Tanya, this year our land turned saline.' Evdokiia Ivanova, whom we met earlier, lamented this turn of events to me shortly after I dropped by to see her in early August 2013. The yard where she lives with her husband, daughter, and grandson lies adjacent to a yerik about 25 meters from the main branch of the Danube. The plot's once island-like form is visible no longer because the canals have been filled in on two sides of the plot. 'We need the canals for drainage. Otherwise the salt rises up from the sand underneath the silt. You know, this used to be the bottom of the sea.' Transformation of her yard into solonchak (saline earth) dramatically reduced the area on which she could grow vegetables. 'Is there anything that can be done?' I asked as we stood looking at her dead raspberry patch. Yerik nado kopat. 'We should dig up the yerik. But who will do it?' Her husband and daughter's health problems prevented them from digging and her grandson was not strong enough to do the volume of digging needed to add a thick enough layer to 
the plot. However, even if there were someone to dig, the silt in this canal was poor quality because it rarely received a fresh deposition.

This paper makes the case for the inclusion of ethnographic analyses of terrestrialization as part of an amphibious anthropology, not only to enlarge and refine this discussion, but also to draw attention to the ecological and social predicaments created by an excess of silt in a Danubian 'town on water'. To do so requires that practitioners of amphibious anthropology go further in circumventing the land/water binary than they have done so far. This means following the people who inhabit muddy places, and avoiding the habit of assuming a priori the discrete existence of land and water as such. This enables us to trace how and why the separations occur along with the changing valuations of different states of matter and kinds of places.

While Vilkovchani's narratives of settlement echo enlightenment narratives, in practice they did not value land over water but instead engaged in a multiplicity of practices aimed at stemming or encouraging certain states of matter (liquid, solid, wet, dry). This makes apparent the specific ways in which systems of valuation and practice transformed, as new infrastructures, forms of employment, and consumer desires emerged under socialism and post-socialism.

While Vilkovo's terrestrialization is occurring partly because of hydrological change caused by the construction of dams upstream, the PMK canal, and shipping channels in other parts of the Danube Delta, it is also the outcome of residents' political ecological encounter with Soviet modernity and its unraveling after the Soviet Union's demise. Water circulating through pipes made people less dependent on ensuring water flowed in the canals near their homes. Employment in land-based enterprises meant having a clear passageway to the river was no longer a necessity of life. Becoming a modern Soviet citizen meant desiring and then accessing (as best as possible) consumer items such as cars, and creating the conditions to use them by filling in canals to create roads and driveways. In independent Ukraine, by contrast, the deindustrialization of rural areas in the context of long-term economic crises during the transition to capitalism has reduced the population and available labor to dig up canals. Meanwhile the expansion of the state in other areas such as environmental regulation has made large-scale sediment removal more difficult.

Vilkovo also reminds us that increased inundation is not always the most immediate problem confronting delta dwellers. In the short term, siltation may be more of a problem than inundation. However, as in all towns, differently positioned Vilkovchani value and advocate the maintenance of wet and dry spaces. While tourism entrepreneurs wish to preserve the canal system, fishermen are more interested in maintaining an access point to the river that exacerbates canal siltation.

Development projects frequently cut out complicated ecological, hydrological, and political relations that have produced the situation, in order to make a problem amenable to intervention. In preliminary discussions of designating part of Vilkovo a heritage site, the image of Vilkovo's amphibious past is being used to mobilize funds to ensure the canal infrastructure persists in the future; there has also been much hype around the revenues to be garnered from tourism (though it remains to be seen just how many people can benefit from it). However, without attending to the current relationships Vilkovchani have with canals, their desire for wet and dry places, how they encourage or limit flows and sedimentation, 
and their capacity to do the labor to maintain them, a restoration project may only create more disruption and disappointment.

\section{NOTES}

1 I would like to express my gratitude to the residents of Vilkovo who have taught me about the intricacies of living in the plavni along the Danube's Kiliia arm, particularly those named in the text. I am especially grateful to Nikolai Izotov who has dedicated a great deal of time to making sure I understood the many nuances of caring for canals. Finally, I would also like to thank Franz Krause, Luisa Cortesi, Derek Hall, Gisa Weszkalnys, Brian Hall, the participants of the Land Imaginations workshop held at the University of Leipzig in March 2018, two anonymous reviewers, and Suomen Antropologi editor Andrew Graan for providing feedback that has greatly improved this article.

2 On April 9, 2015, Ukraine's parliament passed what have been called Decommunization Laws in response to the Maidan Revolution, Russia's annexation of Crimea, and Russia's role in the war in the Donbas region of eastern Ukraine (Shevel 2016). One of these laws required the renaming of toponyms that carried the names of persons associated with the Communist Party and the establishment and maintenance of Soviet power (Gnatiuk 2018: 5). Since the bulk of the research for this article was conducted prior to the passage of these laws I use the street names used prior to 2015 and also indicate the new name. Readers familiar with the region will note that some place names and personal names have been transliterated into Russian and some into Ukrainian. The maps use Ukrainian transliterations to convey official spellings of place names. While I transliterate the Odesa region in which the town is located into Ukrainian, because this article aims to convey place-based knowledge and my interlocutors all spoke to me in Russian, in the text itself I have transliterated the town's name and its street names into Russian (Vilkovo) rather than Ukrainian (Vylkove).

3 Old Believers are descendants of a group of religious dissenters who refused to accept liturgical reforms imposed by Patriarch Nikon. After separating from the Russian Orthodox
Church in 1666, hundreds of thousands of people migrated to neighbouring states or to territories only weakly controlled by the Russian state in order to avoid persecution (Prigarin, 2010: 30). There are different branches of Old Belief and practice varies considerably. A key distinction is drawn between groups with priests (poportsy) and groups without priests (bezpopovtsy). Old Believers in Vilkovo, and in many settlements along the Danube, are poportsy. See Prigarin (2010), especially Chapter 1 on the migration of Old Believers to the Danube.

4 In this article I mainly use the word silt, which is $i l$ in Russian and mul in Ukrainian, rather than the more technical term sediments (which is nanosy in both Ukrainian and Russian) because silt was the term used by residents and town officials. Silt makes up about $85-90 \%$ of the suspended sediments in this part of the Danube. The remainder is comprised of clay and sand (Tymchenko 1996).

5 Pseudonyms have been used to protect people's privacy. Three exceptions are Nikolai Izotov, a Vilkovo guide who has appeared in several films and articles, Volodymyr Ehorashchenko, an engineer, and the Deputy Mayor of Vilkovo, Ivan Soloviev, all of whom gave me permission to use their names.

6 In 1746, the town's official founding date, (though the earliest documentation is from the 1771) it was part of the Ottoman Empire; 1812Russian Empire; 1856-Ottoman Empire and the Danube Principalities, or the Principalities of Moldova and Wallachia (the border ran along Belgorod Channel which divides the town); 1878 Russian Empire; 1918- Romania; 1939-USSR; 1941-Romania; 1944-USSR; 1991-Ukraine.

7 Interview with Volodymyr Ehorashchenko, engineer, September 24, 2012.

8 Vasyl Fedorenko, Deputy Director of the Danube Biosphere Reserve, interview October 30, 2017. Currently approximately 300 people earn some income from working as cooks, guides, pilots, cleaners and accommodation at high season (July, August) for one of the 6 locally owned, officially registered firms or as unregistered entrepreneurs, although not even the owners of the two most profitable firms rely on it as the sole source of income. For those not involved in tourism, the downside is the higher prices, which hits pensioners particularly hard. 
9 See the international conference on amphibious architecture, design and engineering http://www. icaade2015.com/

10 Roughly $2 / 3$ of Vilkovo's population are Old Believer and $1 / 3$ is Ukrainian. While Lipovan and Ukrainian are salient identities, and there are important differences in traditional house construction (see Dushakova 2013 \& 2016), the differences among them were not expressed in terms of the modes of habitation described here.

11 While rich fish stocks in the Ottoman-controlled delta initially drew Old Believer and Ukrainian Cossack settlers seeing refuge from the Russian state, residents have been cultivating orchards and gardens on the islands comprising the Kiliia Delta since the late- $19^{\text {th }}$ century. See Richardson 2015a.

12 Karael is the local name for a northwesterly wind and means 'black wind' because it is associated with storms when fishermen remain on shore. Purias is a north-easterly wind and is based on a word borrowed from Turkish which was borrowed from a Greek word for the God of the Northern wind. Abazia is a southeasterly wind and the name is derived from the fact that it blows from the direction of Abkhazia (SilantievaSkorobogatova et al. 1996: 153-5).

13 Dushakova (2016) refers to elderly people's accounts of stilt houses in Old Believer settlements in the Danube Delta but does not specify the location.

14 River in Russian is reka and is of the female gender.

15 Many people indicated that they will not connect to the vacuum system built by the EU project because they cannot afford it or do not want to pay to connect to it. Many remain skeptical about whether it will work and are frustrated by the damage to roads the system's construction caused.

16 With the exception of several apartment blocks built in the 1960s, homes are heated by coal, while stoves are fueled with gas bolonchiki (canisters). The communal services department extended the electricity, constructed roads, and built a water purification plant and basic pipe infrastructure. Running water was provided, but the town has no sewage system; people have a series of drainage pits (yama) (for the kitchen and bathhouse) in addition to a latrine pit for their toilet. While the communal services department laid primary pipes, neighbors had to pool resources, coordinate labor, and lay the extensions themselves.
17 The acronym of the state enterprise that dug it: Peredvizhnaia mekhanizirovanaia kolona.

18 The 'Dogs' of the title refer to police and other inspectors who lurked there to catch fishermen returning home with illegally caught fish.

19 By the late 1980s, out of a population of 11,022 , approximately 1,800 people were employed in the fishing collective and fish cannery.

\section{REFERENCES}

Anand, Nikhil 2011. Pressure: The PoliTechnics of Water Supply in Mumbai. Cultural Antbropology 26 (4): 452-464.

http://doi.org/10.1111/j.1548-1360.2011.01111.x.

Anonymous author 2015. V Vilkovo opredelili prioritey strategicheskogo razvitiia ('Vilkovo Decided on Its Priorities for Strategic Development'). Dumskaia.net, 28 September.

http://dumskaya.net/news/v-vilkovo-opredeliliprioritety-strategicheskogo-050848/.

<accessed 5 February 2019>

Anonymous author 2017. Vilkovo mozhet lishitsia svoiei samobytnosti $\mathrm{i}$ poteriat interes $\mathrm{u}$ turistov ('Vilkovo Could Lose its Distinctiveness and Cease to be of Interest to Tourists'). Ivasi.nerws, 13 March. http://ivasi.news/pepper/vilkovo-mozhet-lishitsyasvoey-samobyitnosti-i-poteryat-interes-turistov/. <accessed 5 Ferbruary 2019>

Banaszkiewicz, Magdalena, Nelson Graburn and Sabina Owsianowska 2017. Tourism in (Post) socialist Eastern Europe. Journal of Tourism and Cultural Change 15 (2): 109-112.

https://doi.org/10.1080/14766825.2016.1260089.

Barnes, Jessica 2014. Cultivating the Nile: The Everyday Politics of Water in Egypt. Durham: Duke University Press.

Barnes Jessica and Samer Alatout 2012. Water Worlds: Introduction to the Special Issue of Social Studies of Science. Social Studies of Science 42 (4):483-488.

http://dx.doi.org/10.1177/0306312712448524.

Basso, Keith 1996. Wisdom Sits in Places: Landscape and Language Among the Western Apache. Albuquerque: University of New Mexico Press. 
Bassov, Nikolai 2008. Vilkovo: Gorod 3 tserkvei, 72 ostrovov i beskonechnikh kanalov ('Vilkovo: A Town of 3 Churches, 72 Islands and Endless Canals'). Odessa: Astroprint.

Blackbourn, David 2006. The Conquest of Nature: Water, Landscape and the Making of Modern Germany. London: John Cape.

Bell, Sandra 2001. Conservation Versus Livelihood in the Danube Delta. Anthropology of East Europe Review 19 (1): 11-16.

Blok, Anders, Moe Nakazora and Brit Ross Winthereik 2016. Infrastructuring Environments. Science as Culture 25 (1): 1-22.

https://doi.org/10.1080/09505431.2015.1081500.

Bruisch, Katja 2018. Nature Mistaken: ResourceMaking, Emotions and the Transformation of Peatlands in the Russian Empire and the Soviet

Union. Environment and History

https://doi.org/10.3197/0967340

18X15254461646567.

Carse, Ashley 2014. The Big Ditch: Politics, Ecology and Infrastructure at the Panama Canal. Cambridge: MIT Press.

Chelcea, Liviu, and Gergo Pulay 2015. Networked Infrastructures and the 'Local': Flows and Connectivity in a Postsocialist City. City 19 (203): 344-355. https://doi.org/10.1080/13604813.2015.1019231.

Collier, Stephen J. 2004. Pipes. In Patterned Ground: Entanglements of Nature and Culture. London: Reaktion Books.

Cons, Jason 2017. Seepage. Theorizing the Contemporary. Cultural Antbropology Website, 24 October. https://culanth.org/fieldsights/1244-seepage. $<$ accessed 5 February 2019>

Cons, Jason 2018. Staging Climate Security: Resilience and Heterodystopia in the Bangladesh Borderlands. Cultural Antbropology 33 (2): 266-294. https://doi.org/10.14506/ca33.2.08.

Dorondel, Stefan, and Veronica Mitroi 2017. Nature, State and Conservation in the Danube Delta: Turning Fishermen into Outlaws. In Wilko Graf von Hardenberg, Matthew Kelly, Claudia Leal, and Emily Waklid (eds). The Nature State: Rethinking the History of Conservation. London: Routledge.
Dushakova, Natal'ia 2013. Specifics of the Traditional Culture of the Old Believers of Moldova and Southern Ukraine: Dwelling Practices. Anthropology \& Archeology of Eurasia 52 (1): 22-38. https://doi.org/10.2753/AAE1061-1959520102.

Dushakova Natal'ia 2016. Zhilishchnaia praktika Lipovan i Nekrasovtsev: Konfessionalnyi i regionalnyi srez traditsii ('The Dwelling Practices of Lipovans and Nekrasovtsy: A Confessional and Regional Cross-section of Traditions'). Etnograficheskoie obozrenie (2): 148-168.

Dykhno, Natalia 2015. Vylkove: Misto oliharkhiv iz mozoliamy ('Vylkove: A Town of Oligarchs with Calluses'). Leviy Bereh, 5 November.

https://1b.ua/society/2015/11/05/320030_vilkovemisto_oligarhiv_iz_mozolyami.html.

<accessed 5 February 2019>

Feaux de la Croix, Jeanne 2011. Moving Metaphors We Live by: Water and Flow in the Social Sciences and Around Hydroelectric Dams in Kyrgyzstan. Central Asian Review 30 (3-4): 487-502.

https://doi.org/10.1080/02634937.2011.614097.

Feaux de la Croix, Jeanne 2014. 'Everybody Loves Flow': On the Art of Rescuing a Word from Its Users. Suomen Antropologi: Journal of the Finnish Anthropological Society 39( 2): 97-99.

Feau de la Croix, Jeanne 2016. Iconic Places in Central Asia: The Moral Geography of Dams, Pastures and Holy Sites. Bieldfield: Transcript.

Fedorenko, Vasyl Arsenievich 2006. Zapovednaia delta Dunaia i sudokhodstvo: Deklaratsiia $i$ realnost ('Nature Conservation and Shipping in theDanube Delta: Declarations and Reality'). Vilkovo: ARTVISION.

Furlong, Kathryn 2014. Beyond the 'Modern Infrastructure Ideal': Extending Theory by Engaging Infrastructure Challenges in the South. Technology in Society 38 (1): 139-147.

https://doi.org/10.1016/j.techsoc.2014.04.001.

Gagné, Karine and Mattias Borg Rasmussen 2016. Introduction-An Amphibious Anthropology: The Production of Place at the Confluence of Land and Water. Anthropologica 58 (2): 135-149. https://doi.org/10.3138/anth.582.T00.EN. 
Giblett, Rod 1996. Postmodern Wetlands: Culture, History, Ecology. Edinburgh: Edinburgh University Press.

Giosan, Liviu, Jeffrey Donnelly, Emil Vespremeanu, Janok Bhattacharya, Cornel Olariu and Frank S. Buonaiuto 2005. River Delta Morphodynamics: Examples from the Danube Delta. In Liviu Giosan and Janok Bhattacharya (eds). River Deltas: Concepts, Models and Examples. Society for Sedimentary Geology Special Publication. https://doi.org/10.2110/pec.05.83.

Gnatiuk, Oleksiy 2018. The Renaming of Streets in Post-Revolutionary Ukraine: Regional Strategies to Construct a New National Identity. AUC Geographica 53 (2): 119-136.

https://doi.org/10.14712/23361980.2018.1353.

Graham, Stephen and Nigel Thrift 2007. Out of Order: Understanding Repair and Maintenance. Theory, Culture E Society 3 (1):1-25.

https://doi.org/10.1177/0263276407075954

Grupposo, Paolo 2017. Geologic and Historical, Surface and Depth. Entanglement of Water and Temporality in a Contested Wetland of Agro Pontino. Archivo Antropologico Mediterraneo 19 (2): 69-79.

Hastrup, Kirsten and Frida Hastrup (eds) 2016. Waterworlds: Anthropology in Fluid Environments. Oxford: Berghahn.

Helmreich, Stefan 2011. Nature/Culture/Seawater. American Antbropologist 113 (1): 132-144. https://doi.org/10.1111/j.1548-1433.2010.01311.x.

Hudson, Brian J. 1996. Cities on the Shore: The Urban Littoral Frontier. London: Pinter.

Ingold, Tim 2000. Perception of the Environment. London: Routledge.

Iorga, Alexandru 2016. 'Hay Days in the "Black Forest"-Field Notes and Photographs from Caraorman, The Danube Delta.' Martor 21: 197-203.

Ivan, Oana 2017. 'We Make More Money Now, But We Don't Talk to Each Other Anymore': On New Tourism and Capitalism in the Danube Delta. Journal of Tourism and Cultural Change 15 (2): 122135. https://doi-org.libproxy.wlu.ca/10.1080/147668 25.2016.1260102.
Janvier, Philippe 2010. 'Terrestrialization: The Early Emergence of the Concept.' In Marco Vecoli, Gaël Clement and Brigitte Meyer-Berthaud (eds.). The Terrestrialization Process: Modelling Complex Interactions at the Biosphere-Geosphere Interface. London: The Geological Society.

Jensen, Casper Bruun 2017. Amphibious Worlds: Environments, Infrastructures, Ontologies. Engaging Science, Technology, and Society 3: 224-234.

Kane, Stephanie 2012. Where Rivers Meet the Sea. Philadelphia: Temple University Press.

Khan, Naveeda 2014. Dogs and Humans and What Earth Can Be: Filaments of Muslim Ecological Thought. Hau: Journal of Ethnographic Theory 4 (3): 245-264. https://doi.org/10.14318/hau4.3.015.

Krause, Franz 2014. What to Do About Flow? A Conversation About a Contested Concept. Suomen Antropologi: Journal of the Finnish Anthropological Society 39 (2): 89-102.

Krause, Franz 2017. Toward an Amphibious Anthropology of Delta Life. Human Ecology. 45 (3): 403-8.

Krause, Franz (ed.) 2018. Delta Methods: Reflections on Researching Hydrosocial Lifeworlds. Cologne: University of Cologne.

Krause, Franz and Veronica Strang 2016. Thinking Relationships Through Water. Society \& Natural Resources 29 (6): 633-38.

https://doi.org/10.1080/08941920.2016.1151714.

Lahiri-Dutt, Kuntala 2014. Beyond the LandWater Binary in Geography: Water/lands of Bengal Revisioning Hybridity. ACME: An Interdisciplinary E-Journal for Critical Geography 13: 505-29.

Lambert, Audrey M. 1971. The Making of the Dutch Landscape: An Historical Geography of the Netherlands. London: Seminar Press Ltd.

Linton, Jamie 2010. What Is Water? The History of a Modern Abstraction. Vancouver: UBC Press.

Loczy, Denes 2007. The Danube: Morphology, Evolution and Environmental Issues. In A Gupta (ed.). Large Rivers: Geomorphology and Management. Hobokken: John Wiley \& Sons. 
Maffii, Sylvia, Enrico Pastori, Angelo Martino, Viktor Simoncic, Sinisa Spegar, et al. 2016. Study on Current Situation and Likely Development of the Bystroe Canal and Kiliya Arm. Transport Dialogues and Interoperability (IDEA II) Final Report.

https://mtu.gov.ua/files/31110551_dod.pdf.

<accessed 5 February 2019>

Matthews, Geoffrey V.T. 1993. The Ramsar Convention on Wetlands: Its History and Development. Le Brassus: Ramsar Convention on Wetlands.

McLean, Stuart 2011. Black Goo: Forceful Encounters with Matter in Europe's Muddy Margins. Cultural Anthropology 24 (4): 213-245. https://doi.org/10.1111/j.1548-1360.2011.01113.x.

Mikhailov, V.N (ed.) 2004. Gidrologiia delty Dunaia ('The Hydrology of the Danube Delta'). Moskva: GEOS.

Mikhailova, M.V., and E. A. Levashova 2001. Sediment Balance in the Danube River Mouth. Water Resources (2): 180-184.

https://doi.org/10.1023/A:1010331717895.

Morita, Atsuro 2016. Infrastructuring Amphibious Space: The Interplay of Aquatic and Terrestrial Infrastructures in the Chao Phraya Delta in Thailand. Science as Culture. 25 (1): 117-140.

Morita, Atsuro and Casper Bruun Jensen 2017. Delta Ontologies: Infrastructural Transformations in the Chao Phraya Delta, Thailand. Social Analysis 61(2): 118-133.

Norwich, John Julius 1982. A History of Venice. New York: Alfred A. Knopf.

Padawangi, Rita, and Mike Douglass 2015. 'Water, Water Everywhere': Toward Participatory Solutions to Chronic Urban Flooding in Jakarta. Pacific Affairs 88 (3): 517-550.

Pauwelussen, Annet and Gerard Verschoor 2017. Amphibious Encounters: Coral and People in Conservation Outreach in Indonesia. Engaging Science, Technology, and Society 3: 292-314.

Poltorak, Volodymyr 2016. Mistobuduvina traditsiia Vylkovoho i rekommendatsii arkhitektora Illi Dombrovskoho 1846 roku ('City Building Traditions of Vylkove and the Recommendations of the Architect Illiia Dombrovskii of 1846').
In Ukraiinsko-Polski Arkhitekturni Vizii: Pobliad Skriz Chasy Ta Epokby. Kharkiv: Kharkiv National University.

Prigarin, Aleksandr 2010. Russkiie staroobradtsy na Dunaiie ('Russian Old Believers on the Danube'). Izmail: 'Smil'-'Archeodoksia'.

Prigarin, Aleksandr 2015. Fishing Traditions among Old Believers in the Danube Delta: Survival Strategies in the 19th Century. In Constantin Iordachi and Kristof van Assche (eds). Biopolitics of the Danube Delta: Nature, History, Policies. Lanham: Lexington.

Prylypko, Oleksandr 2014. Vylkove: Terytoriia pozazemnoho zhyttia ('Vylkove: ATerritory of Extraterrestrial Life'). Den, 26 April. https://day.kyiv.ua/uk/article/podorozhi/vilkoveteritoriya-pozazemnogo-zhittya. <accessed 5 February 2019>

Raffles, Hugh 2002. In Amazonia: A Natural History. Princeton: Princeton University Press.

Richardson, Tanya 2015a. (In)Accessible Land: The Changing Practice and Regulation of Gardening in in the Reedbeds of Ukraine's Danube Delta, In Constantin Iordachi and Kristof Van Assche (eds). Biopolitics of the Danube Delta: Nature, History, Policies. Lanham: Lexington.

Richardson, Tanya 2015b. On the Limits of Liberalism in Participatory Environmental Governance: Conflict and Conservation in Ukraine's Danube Delta, Development and Change. 46 (3): 415441. https://doi.org/10.1111/dech.12156.

Richardson, Tanya 2016. Where the Water Sheds: Disputed Deposits at the Ends of the Danube, In Marijeta Bozovic and Matthew Miller (eds). Watersheds: The Poetics and Politics of the Danube River. Boston: Academic Studies Press.

Richardson, Tanya 2018. Managing Ambiguous Amphibians: Feral Cows, People, and Place in Ukraine's Danube Delta. Canadian Slavonic Papers $60(3-4): 445-70$.

https://doi.org/10.1080/00085006.2018.1473669.

Rykovtsev, Aleksandr 1984. Vilkovo. Odessa: Maiak.

Scaramelli, Caterina 2018a. Fish, Flows and Desire in the Delta. Anthropology News, 12 March. 
Scaramelli, Caterina 2018b. 'The Wetland Is Disappearing': Conservation and Care on Turkey's Kizilirmak Delta. International Journal of Middle East Studies 50 (3): 405-425.

https://doi.org/10.1017/S0020743818000788.

Shevel, Oxana 2016. Decommunization in Post-Euromaidan Ukraine: Law and Practice. PONARS Eurasia. Policy Memo 411. http://www. ponarseurasia.org/memo/decommunization-posteuromaidan-ukraine-law-and-practice. <accessed 5 February 2019>

Silantieva-Skorobogatova, Valentina 1996. Vilkovo: Gorod v delte Dunaiia ('Vilkovo: A Town in the Danube Delta'). Odessa: Chornomoria.

Swyngedouw, Erik 2005. Metabolic Urbanization: The Making of Cyborg Cities. In Nik Heynan, Maria Kaika, and Erik Swyngedouw (eds). In the Nature of Cities: Urban Political Ecology and the Politics of Urban Metabolism. London: Routledge.

Tempeau, Petruta and Kristof Van Assche 2015. Pirates, Fish and Tourists; The Life of PostCommunist Sulina. In Constantin Iordachi and Kristof Van Assche (eds). The Bio-Politics of the Danube Delta: Nature, History, Policies. Lanham: Lexington.

TeBrake, William H. 1985. Medieval Frontier: Culture and Ecology in Rijnland. College Station: Texas A\&M University Press.

ten Bos, Rene 2009. Towards an Amphibious Anthropology: Water and Peter Sloterdijk. Environment and Planning D: Society and Space 27 (1): 73-86. https://doi.org/10.1068/d13607.
Tiner, Ralph W. 2017. Wetland Indicators: A Guide to Wetland Identification, Delineation, Classification, and Mapping. Second Edition. Boca Raton: CRC Press.

Tymchenko, V. M. 1996. Tsei chudovyi ale ne holubyi Dunai ('This Wonderful but not Blue Danube'). In B. D. Romanenko (ed.). Ekolohichni problemy Dunaiskoho baseina v mezhakh Ukraiiny. Kyiv: Hydroecological Association of Ukraine.

Vaccaro Ismael, Krista Harper and Seth Murray 2015. The Anthropology of Postindustrialism: Ethnographies of Disconnection. In Ismael Vaccaro, Krista Harper, and Seth Murray (eds). The Anthropology of Postindustrialism: Ethnographies of Disconnection. New York: Routledge.

Van Assche, Kristof, and Martin Duineveld, Raoul Beunen and Petruta Teampau 2011. Delineating Locals: Transformations of Knowledge/Power and the Governance of the Danube Delta. Journal of Environmental Policy and Planning. 13 (1): 1-21. https://doi.org/10.1080/1523908X.2011.559087.

Voloshkevych, Oleksandr and Vasyl Fedorenko 2007. The Management of the Danube Biosphere Reserve. In Gianfranco Tamburelli (ed.). Biodiversity Conservation and Protected Areas: The Italian and Ukrainian Legislation. Milan: Giuffre Editore.

TANYA RICHARDSON

ASSOCIATE PROFESSOR OF

ANTHROPOLOGY

DEPARTMENT OF GLOBAL STUDIES

WILFRID LAURIER UNIVERSITY

trichardson@wlu.ca 